\title{
ON THE USE OF THE PARTICIPLE FUNCTIONING AS A FINITE VERBAL FORM IN THE CHRONICLE OF JOHN MALALAS
}

It is a remarkable feature of Hellenistic and Byzantine Greek that sometimes a participle appears to be used in the function of a finite verbal form; in the Chronicle of John Malalas, this is a rather common feature, e. g.: $318,8^{1}$ ss: ' $\mathrm{H} \delta \dot{\varepsilon} \beta \alpha \sigma i \lambda \iota \sigma \sigma \alpha$

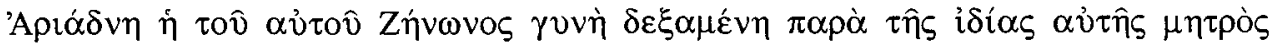

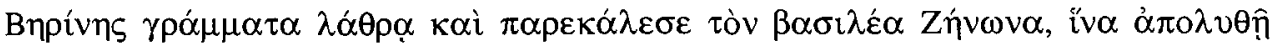

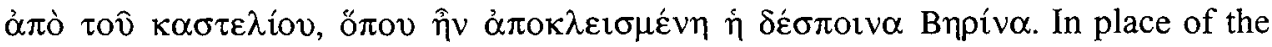
participle $\delta \varepsilon \xi \alpha \mu \varepsilon \dot{v} \eta$, which is not dependent on any finite verbal form in the sentence, a finite verbal form such as the aorist indicative would normally be expected.

Especially when occurring in Byzantine Greek, this is commonly considered to be a mistake, influenced by the process of the participle retreating from spoken Greek, which is supposed to have caused confusion between the syntactical functions of finite and non-finite verbal forms ${ }^{2}$.

However, several arguments could be raised against such explanation:

1. It is questionable if no sense of distinction between finite and non-finite verbal forms existed in spoken Greek. Although the Ancient Greek participle was very likely in the process of retreating in that period ${ }^{3}$, it was never lost entirely, since it changed into the Modern Greek gerund -ov $\alpha \varsigma$, its morphological and syntactical descendant ${ }^{4}$. Such a development does not seem to favour this explanation.

2. The theory presumes that Malalas wrote, at least in some respects, a form of Greek that was very close to the spoken language, a view that can be held at least partially $^{5}$. Horrocks 6 , on the other hand, basing his conclusion on the comparison of Malalas' language with the contemporary papyri, argues that the language of Malalas is still 'very much a written style' and discusses it in the chapter on Middle styles. A great deal of caution is therefore necessary in this regard ${ }^{7}$.

3. The next fact to be considered in connection with the participle functioning as a finite verbal form in Malalas' Chronicle is the occurrence of analogous clauses in earlier Greek. They are rather common in Hellenistic Greek (in the Bible ${ }^{8}$, papyri from the Ptolemaic period on ${ }^{9}$ and in other literature ${ }^{10}$ ), while sporadic use of similar forms can be traced back as early as the Classical period ${ }^{11}$.

Particularly the presence of the participle functioning as a finite verbal form in such an early period as, for example, the Ptolemaic ${ }^{12}$, is significant, since this period shows little evidence that the use of the participle in the function of a finite verbal form could be connected with the development of the Ancient Greek participle as presented above ${ }^{13}$. 
Moreover, there are structural similarities to be noted between different sources of the participle in the function of a finite verbal form. No detailed research on the structure of the clauses with a participle functioning as a finite verbal form has been done, at least as far as Hellenistic Greek is concerned ${ }^{14}$. Nevertheless, the rather sporadic references in various sources suggest that at least one clause structure was quite frequent in Hellenistic and Byzantine Greek, i.e. the structure with the conjunction $\alpha \alpha i$ connecting a participle and a finite verbal form. These references occur in:

- Mayser (1926), 343 ${ }^{15}$ - on clauses with the so-called satztrennende $\kappa \alpha i$ (a term that goes back to Radermacher, cf. below), which were frequent in Ptolemaic papyri.

- Radermacher (1911), 177, 8, on the 'satztrennende k $\alpha$ '' and on other 'satztrennende' coordinating conjunctions (cf. below)

- Jannaris (19682), 405 ( $\$ 1720$ ), who clearly states that in Late and Byz. Greek the conjunction kai could connect a participle and a finite verbal form ${ }^{16}-\mathrm{a}$ fact which is obvious also from the examples quoted on pg. 505 , where this structure ${ }^{17}$ is to be seen in several cases ${ }^{18}$.

- Schwyzer $\left(1959^{2}\right), 407$, a brief mention (cf. footnote 21)

- In regard to Malalas' language, Wolf (1912) 78 noticed this structure to be frequent as well, but he undertook no further research.

- It also frequently occurs in Phrantzes, cf. below.

This is only one of the possible structures (although a frequent one) in Hell./Byz. Greek; not all the clauses with a participle functioning as a finite verbal form follow it: as mentioned above (footnote 17), another possibility is the use of a participle without coordination. Moreover, the relevant information on the Bible is lacking. Nevertheless, such structural similarities show that the use of the participle functioning as a finite verbal form could have been a feature of regular occurrence rather than an incidental mistake.

In Hellenistic Greek, as it is widely observed ${ }^{19}$, the participle could function as a finite verbal form of the indicative or imperative mood.

\section{Some views regarding the participle functioning as a finite verbal form in earlier sources}

The theory that a participle can function as a finite verbal form is commonly attributed to Moulton ${ }^{20}$, who observed this use in the Bible. His views were followed or opposed by a number of scholars ${ }^{21}$.

But, as argued by Frisk ${ }^{22}$, the first question that has to be answered before taking sides is about the exact meaning of the term 'participle functioning as a finite verbal form' (PFFV), i.e. whether it means that the participle is used as a finite verbal form ("als Verbum finitum") or in the function of/instead of a finite verbal form ("statt Verbum finitum"). In the latter case, the feature discussed would pertain to the field of 
syntax, while in the former case the implication would be that the participle has changed semantically.

1.) It is unlikely that the Ancient Greek participle would have undergone a semantic shift from a non-finite to a finite verbal form, for the reasons already discussed (see above) $)^{23}$.

The problem has therefore to do with the field of syntax ${ }^{24}$. This is also the point of view from which several solutions to the problem have been sought:

The participle that functions as a finite verbal form is an anacoluthon - the most frequent interpretation ${ }^{25}$.

The definition of the anacoluthon as given by Schwyzer ${ }^{26}$ can be summarized as follows:

- Every divergence from the logically correct way of expression, most commonly discrepancies in case agreement, variations between infinitives and dependent clauses and the like.

- The process that leads to an anacoluthon is triggered by several circumstances: in natural speech, when psychological factors prevail over grammatical rules (e.g. in Herodot), and in literature, when it is intentionally used as a figure of speech (e.g. in Thucydides) or when it is intended to create an illusion of natural speech (e.g. in Plato).

- Most commonly, it occurs in longer sentences, particularly in the sentences with a parallel structure, and near a pause; the anacoluthon most frequently occurs in the second part.

By considering the PFFV in the light of this definition, certain observations can already be formed at this point:

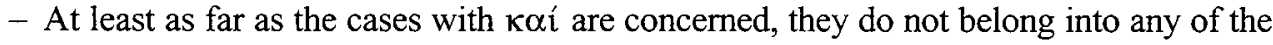
typical groups of the anacoluthon (if the last possibility, 'and the like', is neglected).

- Since the PFFV occurs mainly in non-literary sources, it is not likely to have been used as a figure of speech: and since its existence in spoken Greek in questionable, it is not likely to have been used to imitate natural speech.

2.) A participle functioning as a finite verbal form is a solecism ${ }^{27}$.

That a PFFV would be a syntactical mistake caused by ignorance ${ }^{28}$ is a less probable explanation, for the reasons stated above.

\section{The origin of the participle functioning as a finite verbal form}

Regardless of whether the above constructions are labelled anacoluthic or solecistic, the question of their origin still remains unsolved. There are several views on this point:

Ellipsis of the verb 'to be':

This is Radermacher's ${ }^{29}$ view on the origin of the PFFV (i.e. on some of the types of the use, cf. below), as well as, in broad lines, Wolf's (cf. below). The source of the 
PFFV would therefore be periphrastic verbal forms consisting of participles and the verb 'to be'. A possible counter-argument, however, is that these forms were neither frequent enough in Greek nor generally identical enough with the non-periphrastic forms to make the explanation convincing.

2. As it appears from Radermacher's discussion of the participle, one type of clause is in any case excluded from the above explanation. Namely, a sentence ${ }^{30}$ where the conjunction $\kappa \alpha i$ connects a participle and a finite verbal form (the participle thus functioning as a finite verbal form) is seen as a continuing line of development originating from sentences where the conjunction $\kappa \alpha i$ (the so-called 'satztrennende $\kappa \alpha i$ ') connects several participial constructions in a 'grammatically correct ${ }^{31}$ ' sentence. As examples of the latter he quotes two passages from Hellenistic literature (Polybius and Diodorus), where such constructions were particularly popular ('beliebt'). Their structure is the following: related participle $+\kappa \alpha \mathfrak{i}+$ genetive absolute + finite verbal form. Further down he speaks of a 'satztrennende $\delta \dot{\varepsilon}^{32}$ ' with similar functions as the 'satztrennende $\kappa \alpha i$ '.

If the first explanation is therefore considered to be a less plausible one, the cases with the 'satztrennende' coordinating conjunctions could be taken as the origin of the other types of the PFFV; subsequently, the participle would have been released from the sentence structure and used also in simple clauses without any (coordinating) conjunction.

In the absence of any more specific data on the frequency of such sentences as quoted by Radermacher, it is impossible to say if this theory can actually explain the Hellenistic use of the PFFV in general and even its earliest appearance in Ptolemaic papyri. But there is a note by Schwyzer ${ }^{33}$ which could be taken at least as a possible confirmation of it. According to this note, several participles could be joined together in one sentence as early as in Homer and Herodot, asyndetically at first and later with coordinating conjunctions.

3. Another solution is suggested by Wolf ${ }^{34}$. He sees the starting point in the spreading of the genetive absolute (GA), which is assumed to have appeared in the function of a finite verbal form first, as a consequence of being used instead of a related participle in the nominative case ${ }^{35}$. The use of the GA instead of the nominative form of a related participle would also be the cause of the nominative absolute (NA), which is supposed to have, under the influence of periphrastic verbal forms, lost the copula and caused the participle in the nominative case to appear in the function of a finite verbal form.

The main weakness of the explanation is that the assumed development is confirmed by no evidence. In the final analysis, it assumes an ellipsis as the final cause, at least as far as the nominative forms of the PFFV are concerned (on which cf. above). Another problem is presented by the assumption that the NA appeared in Greek at a rather late stage; although a typical feature of post-Classical Greek, it can be traced back as early as the Classical period ${ }^{36}$. 
However, at least the possibility that the GA functioning as a finite verbal form (due to its use instead of a related participle) was the earliest and that it influenced the other forms of the PFFV is a possible line of development ${ }^{37}$.

\section{Analysis of Malalas' use of the PFFV}

In The Chronicle of John Malalas, the clauses with the participle functioning as a finite verbal form can be divided into the following classes:

Class 1: the participle is connected to a finite verbal form with the coordinating conjunction $\kappa \alpha i$ ( 38 cases):

the participle precedes the conjunction and the finite verbal form ( 28 cases);

the participle follows the verbal form and the conjunction ( 9 cases);

a finite verbal form is placed between two participles ( 1 case).

Class 2: the participle is used independently, i.e. without any finite verbal form occurring in the same clause ( 29 cases)

Class 3: the participle and the finite verbal form are connected with some other coordinating conjunction, i.e. with $\mu \dot{\varepsilon} v . . . \delta \varepsilon$ ( 1 case), $\delta \varepsilon$ ( 5 cases) or ô̂v ( 1 case).

Class 4: 2 clauses differing from the above types.

\section{Class 1}

The clauses of this class follow two basic rules regarding aspect and tense:

- the PFFV is generally an aorist one ${ }^{38}$

- the clauses regularly refer to the past, the finite verbal form being in the past tense ${ }^{39}$ - a feature that could have been caused by the specific nature of the genre as well.

The participle occurs in different forms, the most common being a nominative form of the related participle (type 1), e.g. 169, 90:

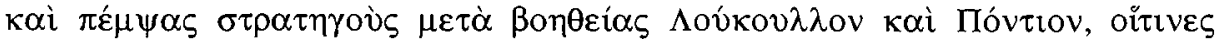

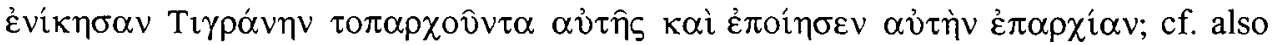
311,8 , as quoted at the beginning of the article.

The second most frequent type is represented by the clauses with the GA functioning as a finite verbal form (type 2). It is represented by 6 clauses, e.g. 72, 75:

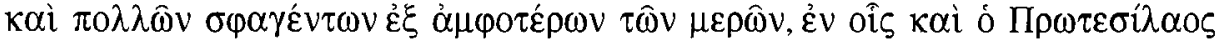

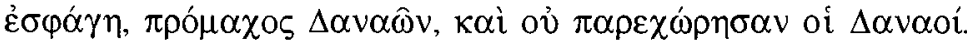

The type with the GA is therefore less frequent, a fact which proves one of the possible views regarding the development of the PFFV (based on Wolf's theory, cf. above) to be less probable. The theory would be more convincing if the data on Malalas' use of the PFFV proved the second type to be more frequent than the first.

Most commonly, the participle precedes its conjunction and its finite verbal form, in the cases with the GA functioning as a finite verbal form as well as in those with a related participle in the nominative. Less frequently, the participle follows the finite verbal form and the conjunction, e.g. 221, 75: 


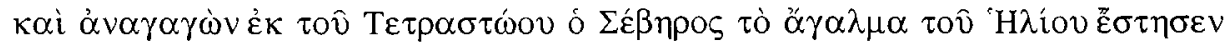

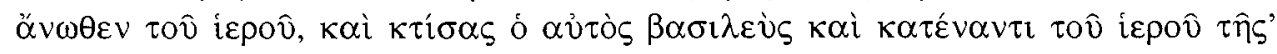

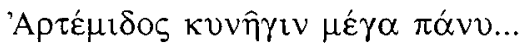

There is only one case $(388,25)$ where the GA functioning as a finite verbal form follows the finite verbal form and the conjunction $\alpha \alpha$ í.

In one case $(332,97)$, the finite verbal form is placed between two participles that function as finite verbal forms.

As for the position of the participle and the finite verbal form, Malalas basically follows the same rules as Phrantzes (cf. below) ${ }^{40}$.

When the conjunction $\kappa \alpha i$ connects the finite verbal form and the related participle in the nominative (type 1), the subject of the participle and of the finite verbal form is identical, while in the case of the GA functioning as a finite verbal form (type 2), the subject of the participle differs from the subject of the finite verbal form. However, in the latter case (i.e. in the case of different subjects), the participle and its subject can also have the nominative form, thus resulting in a construction of nominative absolute (NA) $+\kappa \alpha i+$ finite verbal form (type 3$)^{41}$. There are 4 examples of this type of clause, e.g. 355,39 :

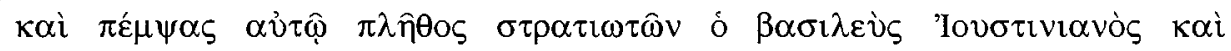

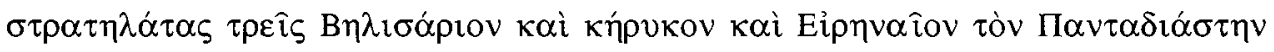

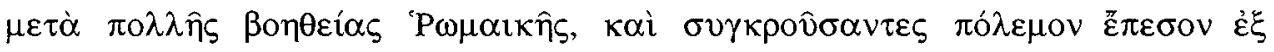
$\dot{\alpha} \mu \varphi \circ \tau \dot{\varepsilon} \rho \omega \nu \pi \circ \lambda \lambda \sigma^{\prime}$.

The participle regularly precedes the conjunction and the finite verbal form.

Since the NA is a rather common feature of Malalas' language ${ }^{42}$ as well as of postClassical Greek in general ${ }^{43}$, this clause type as such presents - from the point of view of Byzantine Greek - the same problems as the types 1 and 2. However, it causes additional difficulties with respect to the origin of the constructions with the PFFV, cf. below (Conclusions).

\section{Class 2}

The above division is partly based on a collection of linguistically significant passages in the Chronicle made by Festugière ${ }^{44}$. Class 1 generally corresponds to the passages quoted by Festugière under the 'superflous кoi' ( $\kappa \alpha i$ surabondant) and Class 2 to Festugière's passages under the 'participe pro verbo finito'. Of the other groups stated above, only clauses with the conjunction $\delta \varepsilon$ (a subdivision of Class 3 ) occur in Festugière as well, under the term 'the superfluous $\delta \varepsilon$ ' ( $\delta \dot{\varepsilon}$ surabondant).

However, the division between the classes 1 and 2 is less clear than it seems.

Thus passage 221, 75 (see above) is considered by Festugière ${ }^{45}$ as an example of a participe pro verbo finito (corresponding to Class 2 in the above categorisation), although, in Dindorf's as well as in Thurn's edition of the Chronicle, the participle is separated from the conjunction $\alpha \alpha i$ and the finite verbal form only by a comma. On the other hand, a comma (and not a semicolon, cf. below) is placed between the par- 
ticiple and the conjunction $\alpha \alpha i$ followed by a finite verbal form in many other passages from Class 1 (or from the group kxi surabondant) ${ }^{46}$. For this reason I attribute passage 221,75 to Class 1, together with all the other cases of analogous punctuation.

More importantly, classes 1 and 2 are connected by the following (structural) characteristics:

a) In both classes, the same rules for the aspect ${ }^{47}$ and tense ${ }^{48}$ are observed. In Class 2, I have found no cases of the present PFFV (nor other participles other than aorist ones).

b) There are several clauses in Class 2 that could be considered as examples of the independent use of the PFFV (and thus as examples of Class 2); they are, however, closely linked to the context and for this reason generally marked with a semicolon at the end. Where the conjunction $\kappa \alpha$ í is placed between the participle and a finite verbal form, the whole construction (the participle together with the conjunction $k \alpha i$ and the finite verbal form) can be seen as an example of the structure belonging to Class 1 . Class 2 as defined above could therefore be subdivided into examples belonging to the proper type of the independent use of the PFFV on the one hand, and into those of a type closely connected to Class 1 on the other.

The proper type is unquestionably represented by passages such as 375,84 , where the whole paragraph consists of a clause with an aorist participle that functions as a finite verbal form ${ }^{49}$ :

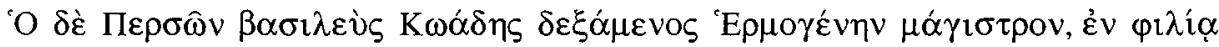

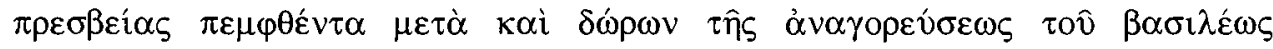

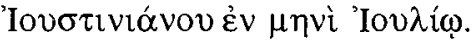

The use of the participle $\delta \varepsilon \xi \hat{\alpha} \mu \varepsilon v o \zeta$ as a PFFV is significant, since the participles of the same verb and of verbs with the same or similar meaning frequently occur in Class 1 , cf. below. There are 17 clauses representing the proper type.

If all the structural possibilities regarding the position and form of the PFFV occurring in Class 1 are taken into account, the structure of the rest of the clauses previously attributed to Class 2 is analogous with the structure of the clauses belonging to Class 1 .

Thus, neglecting the punctuation (cf. above), the following passage $(253,56)$ has the same structure as the clauses belonging to Class 1 .

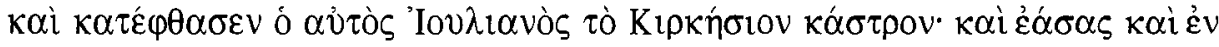

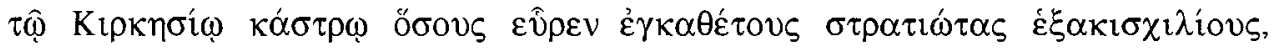

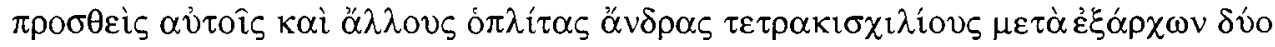

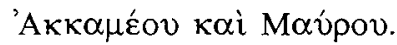

In case these new criteria are applied, even analogous passages with the subject of the participle differing from the subject of the finite verbal form can be regarded as examples of Class 1, since the NA is one of the possible forms of the participle in this class.

Thus the structure of passage 334, 31 :

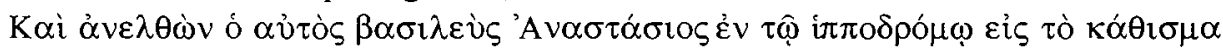

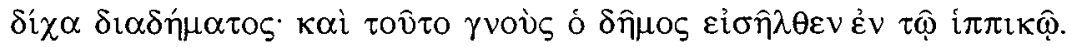

is the same as the structure of the clauses in Class 1, type 3 . 
By these criteria, there are 17 cases of the independent use of the PFFV, and 50 cases where a participle and a finite verbal form are coordinated.

c) As mentioned above, some verbs seem to occur more frequently than others, leading to the assumption that the PFFV was limited to certain verbs or verbs of certain semantic groups. Examples:

- The participle $\delta \varepsilon \xi \alpha \dot{\alpha} \mu \varepsilon v \zeta$, found in one of the most certain cases of the independent use of the PFFV, occurs also in Class $1(311,8 \text {, quoted initially })^{50}$; together with participles such as $\lambda \alpha \beta \omega \nu$ ( $2 \mathrm{x}$ in Class 1 and $1 \mathrm{x}$ in Class 2$), \dot{\varepsilon} v \tau v \chi \omega \nu$ ( $1 \mathrm{x}$ in Class $1)$ and $\pi \alpha \rho \alpha \lambda \alpha \beta \omega v(2 x$ in Class 1 and $1 x$ in Class 2$)$ it could form one of the semantic groups (represented by 9 cases).

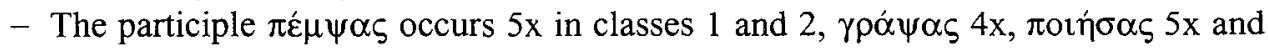

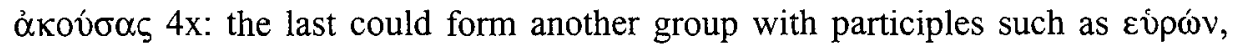

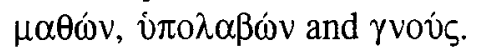

- Another peculiarity has to do with the broader context of how the above verbs are used. In passage $390,85 \mathrm{ss}$, a PFFV is used 3 times in 3 consecutive sentences

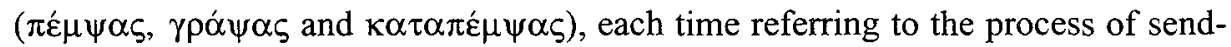

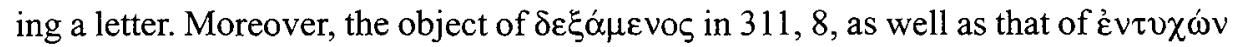
in 389,57 , is a letter $(\gamma \rho \alpha \mu \mu \mu \alpha \tau)$; the participle $\gamma \rho \alpha \psi^{\prime} \alpha \alpha_{\varsigma}$ is used in a similar context in 394,20 ss.

Thus the meaning, apart from merely imposing a constraint on the PFFV, could also represent the third link between classes 1 and 2 .

The figures, on the other hand, are not necessarily to be taken as conclusive, especially as no comparison with other sources can be made due to the lack of data. They could be a mere coincidence, caused by the length of the Chronicle and by Malalas' vocabulary, which is not particularly rich. Moreover, similar limitations could have existed in the other classes ( 3 and 4 ) as well, which are represented by far too small a number of examples.

As far as the connection between classes 1 and 2 is concerned, the above observations (under $a$ ) and b)) are therefore more conclusive.

\section{Class 3}

The examples in this group are much rarer and often disputable. As stated in Wolf ${ }^{51}$, besides the conjunction $\kappa \alpha \dot{i}$, also the coordinating conjunctions $\dot{\alpha} \lambda \lambda \dot{\alpha}, \delta \dot{\varepsilon}$ and ồv can connect a participle and a finite verbal form.

I have found no examples of this use of the conjunction $\dot{\alpha} \lambda \lambda \dot{\alpha}$, neither are they quoted in Festugière (or Wolf).

In one case, a participle and a finite verbal form are connected by $\mu \grave{\varepsilon} v . . . \delta \dot{\varepsilon}$. The participle ( $\varepsilon \sigma \tau \omega \tau \omega v)$ has the meaning of the present aspect, although morphologically it is a perfect participle. The structure of the clause corresponds to some of the cases given by Schwyzer ${ }^{52}$ as examples of the anacoluthic use of the participle in Classical Greek. 
In addition to the conjunction $\mu \grave{\varepsilon} \nu \ldots . . . \delta \dot{\varepsilon}, \delta \varepsilon$ alone can connect a participle with a finite verbal form, e.g. 174,78

$\kappa \alpha i$ દ̉pó $\sigma \theta \eta \ldots \tau$...

To the three passages quoted by Festugière ${ }^{53}$ two more can be added. As it appears from Festugière's list, no rules regarding the verbal aspect seem to apply. Generally, such cases are too scarce to allow any specific conclusions. In Phrantzes, they occur just as rarely as in Malalas (4 occurrences).

Festugière provides no examples of oûv connecting a participle with a finite verbal form, neither does Wolf. Passage 180,12, quoted below, can be, however, taken as a representative of the type. Here, the conjunction oûv connects a perfect participle ( $\dot{\alpha} \kappa \eta \kappa о v \hat{\imath} \alpha)$ with a finite verbal form ( $\delta \delta \rho \alpha \mu o v)$. The passage is exceptional for various reasons and it generally eludes the explanations of the other classes. No examples of this type have been found in Phrantzes either.

\section{Class 4}

There are two clauses that do not follow any of the above principles of the PFFV. The first is passage 217,10 , quoted by Wolf ${ }^{54}$ as the only example of the coordination of a participle and a finite verbal form in a dependent clause ${ }^{55}$. The conjunction $\kappa \alpha$, however, does not connect a participle and a finite verbal form ${ }^{56}$ in this case; rather, it connects a participle ( $\varphi$ ов́ $\sigma \alpha \varsigma$ ) and a pronoun ( $\alpha$ v̉ós). It is not to be translated as 'and', but as 'too' 57 . For this reason, this passage cannot belong to Class 1 .

This clause seems particularly peculiar: it contains two successive participles that function as finite verbal forms, the first one being a present participle ( $\delta \pi \alpha ́ \rho \chi \omega v$ ) and

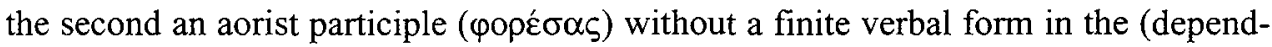
ent) clause. No such groups are found among the clauses of Class 2 , where the passage could possibly belong.

The second passage $(180,12)$ is the following:

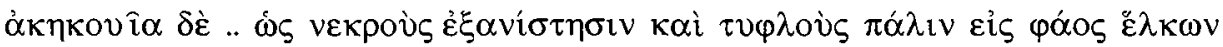

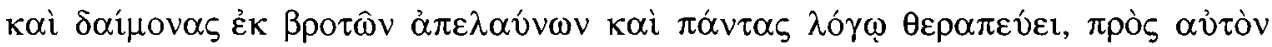

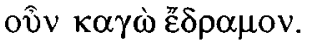

The passage is exceptional due to the following characteristics:

- It is the only case where a participle and a finite verbal form are coordinated by oûv. It could be considered as belonging to Class 1 (since it is the conjunction $\alpha \alpha$ i that connects the participles with the finite verbal forms in the dependent clause $\omega \varsigma$ ), but it is excluded from the group by the following characteristics:

- If the participles $\check{\varepsilon} \lambda \kappa \omega \nu$ and $\dot{\alpha} \pi \varepsilon \lambda \alpha \hat{v} v \omega v$ are interpreted as instances of the PFFV (and not as participial complements of the verb $\alpha \kappa o v \omega$, which was a possibility in Classical as well as in post-Classical Greek ${ }^{58}$ ), the passage does not follow the general rule for the aspect of the participle in this group. 
- In the clauses of Class 1 , the actions expressed by the participle and the finite verbal form are generally consecutive ${ }^{59}$, which is not the case in this clause: here, the actions are simultaneous.

- The way the conjunctions $\kappa \alpha$ í connect the present participles ( $\varepsilon \lambda \kappa \omega \nu$ and $\dot{\alpha} \pi \varepsilon \lambda \alpha v v \omega v$ ) with the finite verbal forms $\dot{\xi} \xi \alpha v i \sigma \tau \eta \sigma \iota v$ and $\theta \varepsilon \rho \alpha \pi \varepsilon v$ vi (finite ver-

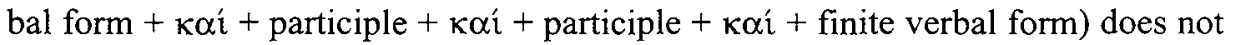
correspond to any of the types of Class 1 .

- The instances of the PFFV occur in a dependent clause (cf. footnote 55).

What distinguishes the passage from all the other groups is the fact that it is clearly a quotation from an earlier source (cf. the opening phrase on page 180 (Thurn

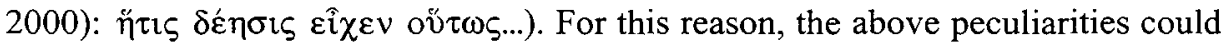
be explained as reflecting a use of the participle that was more common in an earlier period.

\section{Comparison between Malalas and Phrantzes}

If the above characteristics are compared with the data on Phrantzes' use, offered by Stepski Doliwa ${ }^{60}$, the following conclusions are possible:

- Most commonly, the participle is a PFFV when it is connected with a finite verbal form by the conjunction k $\alpha$ i (Phrantzes: 98 cases out of 104).

- In the majority of occurrences, the participle precedes the conjunction and the finite verbal form.

- The only construction appearing in Malalas and not in Phrantzes is the coordination of the NA and a finite verbal form. Otherwise, the clause types are very similar.

- In regard to the verbal aspect, Malalas regularly uses the aorist participle in the function of a finite verbal form, while the relevant data for Phrantzes are lacking.

\section{Conclusions}

The majority of the clauses in the Chronicle of John Malalas containing a PFFV can be considered as a class which follows two basic rules:

a) The participle and the finite verbal form are connected with the coordinating conjunction $\kappa \alpha i$.

b) The PFFV is one of the aorist aspect, generally referring to the past; but the latter could have been partially or entirely caused by the specific nature of the literary genre.

The definition of the PFFV as an anacoluthon seems less convincing. The following can be added to the previous remarks ${ }^{61}$ : as Malalas' text reveals particularly well, the use of the participle in the function of a finite verbal form in the above defined group was regular and subject to rather strict rules ${ }^{62}$. It is therefore questionable whether it can be regarded as contradicting the logical way of expression and whether at least the examples in this group were felt as such. The fact that the participle tends to precede the finite verbal form does not seem to agree with the above definition of 
the anacoluthon, by which it is the second element of a structure that is commonly the anacoluthic one.

As the comparison of Phrantzes and Malalas shows, this type of expression could be a feature of Byzantine historiography. The Byzantine historians could have been influenced by the non-literary writings of Late Antiquity, where identical constructions can be observed, although no exact data exist.

The origin of the PFFV: it is not likely that the use was influenced by the process of the disappearing of the Ancient Greek participle, as it cannot be concluded that it ever was a feature of the spoken language. As regards the origin of the cases with $\kappa \alpha i$, the best solution seems to be offered by Radermacher's views on the satztrennende $\kappa \alpha i$, especially if they are understood in a broader sense. A broader view is required for the following reason: in the 2 cases quoted by Radermacher as examples of coordinate participial constructions, it is a related participle in the nominative and a GA that are connected, a condition that seems unnecessary and, because of a present participle being used in one case of the GA, causes additional problems with respect to Malalas. It is more reasonable to assume all the cases with the conjunction $\kappa \alpha$ i connecting several participles - such as quoted by Schwyzer from Homer and Herodot - to be the source of the PFFV, without restrictions on their form. Thus cases like Malalas 60, 21

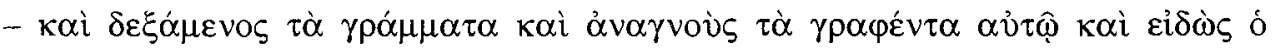

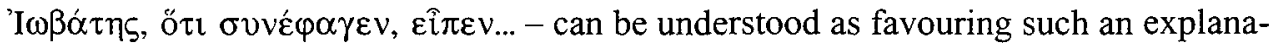
tion.

This could account for the frequent appearance of the conjunction koi near a PFFV. Moreover, an explanation could also be provided of the fact that the aorist participle is used so strictly. The aorist participle expressing a temporary action, the use of the conjunction $\kappa \alpha i$ becomes more necessary when several actions expressed by aorist participles occur in one sentence, since it is the conjunction that makes the course of events clear. If, on the other hand, an aorist and a present participle are used together in a clause, there is less doubt about the exact meaning, since the latter expresses duration and the former perfective action as such. It is significant that among the cases quoted by Schwyzer on pg. 405 (19592), the conjunction kat is the most frequent and commonly occurs with aorist participles ${ }^{63}$. Whether this is a coincidence or not could be made clear only through a research on the relevant passages in Homer and Herodot.

The development as conceived by Wolf, on the other hand, does not give any clues to the basic features of the PFFV, which - together with the reasons already mentioned ${ }^{64}$ - makes the explanation less probable. The same refers to the theory which assumes an ellipsis of the verb 'be' as the main cause.

The fact that only the k $\alpha i$ was so widespread near the PFFV, in contrast to the other coordinating conjunctions, is still not accounted for. It could be explained by the frequency of the $\kappa \alpha^{\prime} i$ itself as the most common coordinating conjunction. The cases with other coordinating conjunctions follow, in terms of their frequency and structure, the 
lines of the analogous use of the participle in Classical Greek; they prove at least that they cannot be a consequence of the participle retreating from the spoken language.

On the other hand, an explanation that goes back as early as the Classical period is confronted with some problems, such as the use of the nominative absolute in the function of a finite verbal form, which could be explained by analogy in this case.

In comparison with earlier cases of the PFFV, Malalas does not use the participle in the function of an imperative verbal form, a feature that might have been caused by the specific nature of the genre.

Finally, there are also examples of the independent use of the PFFV. Connected by various characteristics to the main class, they might well be assumed to have their origin in it, at least as far as the language of Malalas is concerned.

\section{Bibliography}

BLASS/DEBRUNNER/REHKOPF (1976 ${ }^{14}$ ): Grammatik des neutestamentlichen Griechisch, Göttingen

BRowNING (1969): Medieval and Modern Greek, London

DEBRUNNER (1954): Geschichte der Griechischen Sprache II, Berlin

DINDORF (1831): see Malalas (Dindorf 1831)

FestugiĖRE (1979): Notabilia dans Malalas II, Revue de philologie LIII, pg. 227-237

FRISK (1966): Partizipium und Verbum finitum im Spätgriechischen, in: Kleine Schriften, Göteborg

Horrocks (1997): Greek, A History of the Language and its Speakers, London and New York

HUNGER (1978): Die hochsprachliche profane Literatur der Byzantiner I, Munich

JAMES (1990): The language of Malalas, in: Studies in John Malalas, Sydney

JANNARIS (1968²): An historical Greek Grammar, Hildesheim

JEFFrEYs (1986): see Malalas (Jeffreys 1986)

KAZHDAN (1991): The Oxford dictionary of Byzantium. Alexander P. Kazhdan, (ed.), New York-Oxford

KRUMBACHER (18972): Geschichte der Byzantinischen Literatur, Munich

Malalas (Jeffreys 1986): The Chronicle of John Malalas, Sydney

MAYSER (1926): Grammatik der Griechischen Papyri aus der Ptolemäerzeit II, 1, Berlin und Leipzig

Mirambel (1961): Participe et gérondif en Grec médiéval et moderne, in: Bulletin de la société de linguistique

XVI, pg. 46-79

Moulton (1911), Einleitung in die Sprache des Neuen Testaments, Heildelberg

RADERMACHER (1911): Neutestamenliche Grammatik, Tübingen

SCHWYZER (19592): Griechische Grammatik II, Munich

STEPSKı DOLIwa (1935): Studien zur Syntax des Byzantinischen Historikers Georgios Phrantzes, Munich

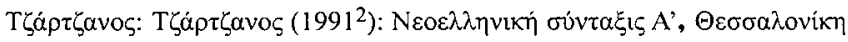

THURN (2000): see Malalas (Thurn 2000)

WeIERHolt (1963): Studien im Sprachgebrauch des Malalas, Symbolae Osloenses, fasc. Supplet. XVIII

WOLF (1912): Studien zur Sprache des Malalas II, Munich

\section{Text editions}

Malalas (Thurn 2000): Chronographia Ioannis Malalae, New York and Berlin

Malalas (Dindorf 1831): Ioannis Malalae Chronographia, Bonnae 


\section{Notes}

I The quotations follow the latest edition of the Chronicle, Thurn (2000).

2 Cf. one of the latest discussions of Malalas' language, James (1990), 220: Decline in the use of participles, also noted above, led to confusion between its syntactical function and that of the finite verb. (The decline is previously understood as the retreat of the Ancient Greek participles and the development of the gerund.); cf also Wolf (1912), 77: "Nun gebraucht aber Malalas die alten Formen sehr häufig, aber in so konfuser Weise, dass man den Eindruck gewinnt, der Mann hatte von der syntaktischen Verwendung und der Bedeutung des Partizips keine klare Vorstellung mehr. Er gebraucht es ... gleichberechtigt neben den Verbum finitum, in unzähligen Fällen an Stelle eines Hauptverbums."

3 Such is basically the view of Browning (1969), 68, who dates the development into the Early Byzantine period or earlier; cf. G. Horrocks (1997), 122 and Mirambel (1961); here, the development in all its stages is dated into the period from 2 nd century AD to 13 th century.

4 It kept the Ancient Greek participial function of an adverbial complement of the main verb, cf. for example Mirambel (1961) 57,8; Browning (1969), 68: ... the majority of participles ... are circumstantial, adverbial in function, playing exactly the same role in the sentence as the Modern Greek indeclinable gerund -ovi 5 which is the continuation of earlier active participles.

5 cf. Krumbacher (18972), 327,8: "Es unterliegt keinem Zweifel, daß wir in Malalas das erste grössere Denkmal der volksmäßigen Gräzitat vor uns haben... So sehr atmet das ganze Werk den vulgärgriechischen Geist, dass sich mit geringen morphologischen und lexikalischen Änderungen Satz fur Satz ins Neugriechische umgeissen läßt. Alle spuren des Volkssprache ... sind hier zum vollen Rechte gekommen"; cf. also Hunger (1978), 323, where this view already seems to be slightly corrected (notice the term 'gehobene Umgangssprache'): "Damit gelang es ihm scheinbar mühelos dem Prokrustesbett des Attizismus zu entgehen und sein Sprachniveau etwa auf gehobene Umgangssprache einzustellen."

6 cf. Horrocks (1997), 180

7 cf. James (1990), 218 (general remarks on the language of Malalas): But a strong note of caution needs to be sounded on the difficulty of contrasting literary Greek with the colloquial language.

8 cf. Moulton (1911), 284-88; 352-56; Blass/Debrunner/Rehkopf (1976 ${ }^{14}$ ), 396 ss; Radermacher (1911), 167, 343.

9 cf. Mayser (1926), 340 ss.

10 cf. footnote 18.

11 cf. Schwyzer (19592), 406: Seit Homer kann eines von zwei koordinierten verbundenen Partizipien (selten das erste) anakolutisch durch ein verbum finitum vertreten werden.

12 cf. Mayser (1926), 340 ss. As we may conclude from the quoted passages, the participle functioning as a finite verbal form appears in papyri as early as 2nd century BC, while Mirambel (1961) 50, 1, quotes the earliest signs of the participle developing towards the gerund from 2 nd century AD.

13 cf. footnote 3

14 Stepski Doliwa (1935), 258-262, on the other hand, gives very detailed information on the use of participles that function as finite verbal forms in Phrantzes, a historian from the Late Byzantine period (15th century). A more detailed comparison between Phrantzes and Malalas will be made below.

15 As far as Ptolemaic papyri are concerned, Mayser opposes the possibility that the participle could function as a finite verbal form, but admits it in regard to Biblical and Byzantine Greek, cf. Mayser (1926), 340: "mag sie (i.e. Moulton's theory on the participle functioning as a finite verbal form) auch in vereinzelten Beispielen für den neutestamenlichen Sprachgebrauch und späteren Perioden ... zutreffen, für die Ptol. Papyri ist sie jedenfalls in keinem Punkte zwingend." The structural similarities, however, do not speak in favour of such interpretation.

16 He calls it a solecism; loc. cit.: K $\alpha$ i in T-B (i.e. Transitional-Byzantine Greek) sometimes connects a participle with its governing verb. For this solecism, see pg. 505.

17 The quoted passages are taken out of theological and technical writings from Late Antiquity, and Malalas.

18 In other cases, the participle is used in an independent clause, without any finite verbal form occurring in the same clause. 

pium statt eines Indikativs oder Imperativs gebraucht werden kann, scheint jetzt durch die Papyri ziemlich sichergestellt zu sein.

20 Cf. Mayser (1926), 340, Schwyzer (19592), 407; Moulton ((1911), 284-88, 352-56, cf. also the above quotation) sees the participle functioning as a finite verbal form as 'a way of expression that comes into being, when indicative or imperative are for any reason set aside' (1911,354): "Diese Analogien seien nur angeführt um zu zeigen, dass der Gebrauch des Partizipium, mit oder ohne Hilfsverbum, stets zur Hand war, so oft der gewöhnliche Indikativ (oder weniger oft der Imperativ) aus irgendeinem Grunde beiseite geschoben wurde."

21 For a detailed list of authors, see Schwyzer (19592), 407; Mayser (1926), Blass/Debrunner/Rehkopf (1976 ${ }^{14}$ ) and Frisk (1966) oppose Moulton's views, mainly by assigning the participle to the categories of the anacoluthon (Blass/Debrunner/Rehkopf, partially Mayser) and solecism (partially Frisk, Jannaris, cf. above), and also by combining several possibilities (Mayser, Frisk), including scribal errors and various phonetic or syntactical interpretations. Schwyzer opposes Moulton's views too. As far as examples from Classical Greek are concerned, he assigns them to the category of the anacoluthon (cf. footnote 11), while the cases with the conjunction $k \alpha i$, mentioned on page 407, are interpreted as belonging under 5 on pg. 406. This interpretation, however, is unclear and confirmed by no examples. On the other hand, Stepski-Doliwa (1935), Radermacher (cf. below), and in some cases Frisk (1966), 62, 65 (on 'Nominalsätze'), agree with Moulton.

22 Frisk (1966), 432.

23 Cf. also Frisk (1966), 432: es ist zu beachten, dass es nicht um eine Bedeutungsverweiterung des Partizipiums in dem Sinne handelt, daß das unmittelbare Sprachgefühle eine partizipiale d. h. nominale Ausdrucksweise nicht von einer verbalen zu unterscheiden wußte.

24 For this reason I use the term 'participle functioning as a finite verbal form' (PFFV).

25 cf. Mayser (1926), 341, where some of the cases are considered to be anacoluthic; Blass/Debrunner/Rehkopf (197614), 396-8, where the whole subject (Partizipium und verbum finitum) is discussed in the chapter Das anakoluth; on Schwyzer cf. footnotes 11 and 21.

$2619592,704,5$

27 cf. Frisk (1966) on some of the cases (pg. 434,5) and Jannaris (19682), 405; as mentioned above, these explanations most frequently occur in connection with cases of the PFFV from later periods. Another difficulty regarding Hellenistic Greek is caused by observations such as Moulton's (1911), 354, that the use of the PFFV is not limited to the documents of vernacular Greek: "Wir können beobachten, dass der eben besprochene Partizipialgebrauch in den Papyri durchaus kein Kennzeichen niederer Bildung ist."

Which is a solecism by definition, cf. for example Kazhdan (1991), s.v.

29 (1911), 167.

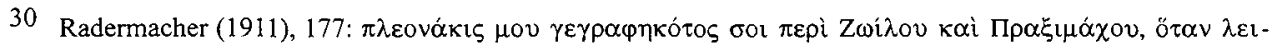

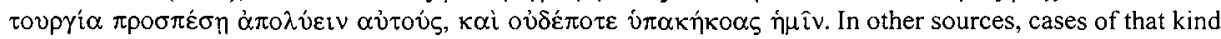
are generally considered to be a PFFV.

31 i.e. from the point of view of the Classical grammar; the conjunction connects several participles dependent on a finite verbal form, and not a participle and a finite verbal form.

32 These clauses show analogous structure with the sentences containing $\mu \varepsilon \dot{v}$.. $\delta \dot{\varepsilon}$, quoted by Schwyzer (19592), pg. 406 and 705 .

33 (19592), 405: Zwei oder mehr Partizipien können seit Homer koordiniert erscheinen, zunächst asyndetisch,

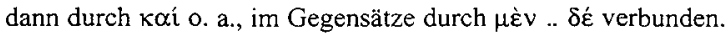

34 (1912), 77.

35 It is a rather common feature of Malalas' language; for passages see Festugière (1979), 235; cf. Weierholt (1963), 71, who also gives an explanation of the feature: Wenn er nun ... eine Periode mit einem gen. abs. beginnt, ohne sich zuerst genau vorzustellen, wie er das Folgende konstruieren wird, ist es natürlich der Gefahr ausgesetzt, sich in der klassichen Regel vom part. coniunct. und dem gen. abs. zu verständigen, was auch nicht ganz selten geschieht.

36 cf. Schwyzer (1959²), 403, Debrunner (1954), 131.

37 Even though in this case the reasons why the GA could have appeared in the function of a finite verbal form in the first place are far from being clear. 
The only passage that can, in my opinion, be regarded as exceptional is 36,46 , quoted also by Festugière (1979), 234, under ' $k \alpha$ i surabondant' (his quotation, 50, 21, follows Dindorf's edition (Dindorf, 1831) of the

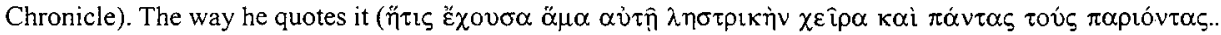

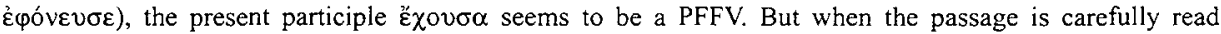
through, the participle $\varepsilon \chi \chi 0 v \sigma \alpha$ turns out to be dependent on another participle in the sentence, $\kappa \alpha \theta \eta \mu \varepsilon \dot{\varepsilon} \eta \eta$. This participle, which is in the present tense as well, is indeed a PFFV, but coordinated with another PFFV in the sentence, $\sigma v v \alpha \gamma \alpha \gamma 0 v 0 \sigma \alpha$, which has the aorist aspect. So the structure of the sentence is: $\sigma v v \alpha-$

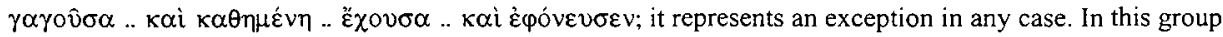
I have found no cases of a present PFFV unaccompanied. As far as passage 254,80 is concerned - also quoted by Festugière under $\kappa \alpha i$ surabondant $($ as 330,18$)$-, the present participle $\beta \circ v \lambda{ }^{\prime} \mu \varepsilon v o \zeta$ refers to the finite

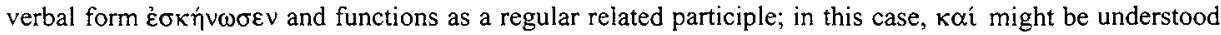
as superfluous in some other sense; cf. also below on passage 180,12, and footnote 57.

With regard to its aspect, the aorist prevails, but the imperfect and the historical present occur as well.

40 As expected, all the examples in Class 1 also correspond to the clause structure mentioned above in connection with the Hellenistic use of the participle functioning as a finite verbal form.

Cf. below on Phrantzes, where only types 1 and 2 appear.

42 Cf. Festugière (1979), 232 and Weierholt (1963), 74.

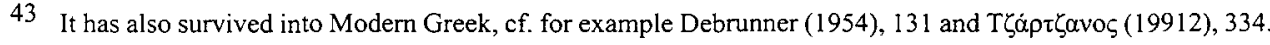

44 Festugière (1979); he quotes 22 passages under participe pro verbo finito, 16 cases under kó í surabondant and 3 cases under $\delta \dot{\varepsilon}$ surabondant. Altogether, my figures are only slightly higher than Festugière's, but much lower than those given by Wolf (1912), 77 . He refers to 'approximately 20 ' cases of the GA functioning as a finite verbal form and 70 cases where a related participle in the nom. and a finite verbal form are coordinated. Unfortunately, he does not quote the passages.

45 Who quotes it from Dindorf (1831) 292, 9.

46 Cf. for example the passages quoted above, as 72,75 or 390,$90 ; 331,55$; or 296,49 .

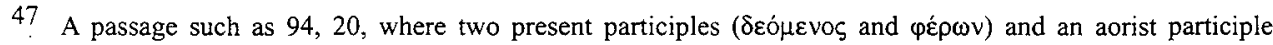
( í $\psi \propto \varsigma$ ) are used in the clause without a finite verbal form, cannot be regarded as exceptional, since the present participles are dependent on the aorist participle; cf. Festugiere (1979), 232, for the same interpretation of the passage: 'ṕi $\psi \alpha \varsigma$ pour $\tilde{p} \rho \rho \downarrow \varepsilon$ '.

48 cf. above on Class 1; in Class 2, the time reference can be deduced from the context.

49 Like Phrantzes, Malalas occasionally uses the GA independently ( 2 cases) as well.

50 Cf. also passage 60,21, quoted in Conclusions.

$511912,78$.

52 19592, 406 and 705; in cases of $\mu \grave{\varepsilon} \nu$.. $\delta \dot{\varepsilon}$ connecting a participle and a finite verbal form, quoted by Schwyzer, the participle occurs in the first part as well; as we may conclude from Schwyzer's quotations, the use of the participle was not limited by the verbal aspect.

1979, 234; he quotes 2 aorist participles and 1 present participle.

541912,78 .

55 I have found no such cases except 180, 12, on which cf. below.

56 Which does not occur in the clause at all.

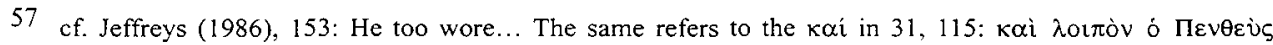

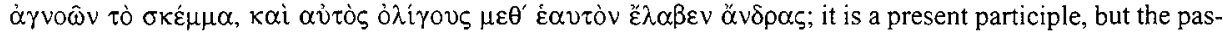
sage is - due to the meaning of $\kappa \alpha i$ - not to be taken as exceptional, as far as the aspect of the participle is concemed. Cf. Mayser (1926), 345 for similar cases in Ptolemaic papyri.

58 The problem with this explanation is, however, that the participles are used in the nominative and not in the genitive or accusative form, one of which would be expected with the verb $\dot{\alpha} \kappa о v \omega$.

59 cf. Stepski Doliwa (1935), 260, on similar observations about Phrantzes.

$601935,258-262$. Since Stepski Doliwa categorises the clauses by criteria different from mine, the figures given below are deduced from the various groups in her categorisation. 
61 cf. the chapter Some views regarding the participle functioning as a finite verbal form in earlier sources.

62 It is also the main feature distinguishing Malalas' use from the similar cases quoted by Schwyzer $\left(1959^{2}\right)$ on pg. 405 and 704. Additionally, in one case, quoted on pg. 704 as an example of the anacoluthic use of the participle, the participle (in the form of the GA) and the finite verbal form are connected with kaiv; however, a present participle alone (oǔons) occurs where a finite verbal form would be expected, on which cf. above, footnote 38 .

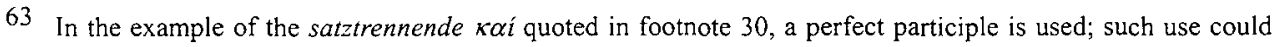
have been influenced by the increasing loss of the distinction between the perfect and aorist tense in Hellenistic Greek; cf. for example Mayser (1926), 139: In der hellenistischen Zeit dringt das Perfekt immer mehr in die Sphäre des Aor. ein und dient als erzählendes Tempus.

64 Cf. above, The origin of the participle functioning as a finite verbal form, 3.

\section{Povzetek}

\section{RABA PARTICIPA V FUNKCIJI OSEBNE GLAGOLSKE OBLIKE V KRONIKI JANEZA MALALASA}

V Kroniki Janeza Malalasa se v večini primerov $v$ funkciji osebne glagolske oblike uporablja particip aorista, ki je $z$ osebno glagolsko obliko povezan s prirednim veznikom k $\alpha i$. Stavki s podobno zgradbo so izpričani tudi $v$ delu bizantinskega zgodovinarja Phrantzesa ter $v$ helenističnih in poznoantičnih neumetnih besedilih. Slednja bi lahko vplivala na bizantinske zgodovinopisce. Vsaj s stališča Malalasovega jezika je možno domnevati, da so takšni stavki vplivali tudi na samostojno rabo participa $v$ funkciji osebne glagolske oblike; $v$ tem primeru ni particip povezan $z$ nobeno osebno glagolsko obliko. Kar se tiče izvora participa v funkciji osebne glagolske oblike, je najbolj upravičeno izhajati iz stavkov, kjer je več participialnih konstrukcij med sabo povezanih z veznikom koí; pogosti so bili tako v klasični kot v helenistični grščini. V nekaj primerih sta particip in osebna glagolska oblika povezana $z$ drugimi prirednimi vezniki; ti stavki so po zgradbi in pogostnosti primerljivi $z$ rabe participa, ki je izpričana že za klasično dobo. 